\title{
Southern occupational therapies: Emerging identities, epistemologies and practices
}

\author{
Alejandro Guajardo, Lic. OT, Lic. Family Therapy, Dipl. Geriatrics and Gerontology \\ Associate Professor, Director of the Occupational Therapy Masters Programme, School of Occupational Therapy, Faculty of \\ Rehabilitation Sciences, Universidad Andres Bello, Santiago de Chile, Chile
}

\section{Frank Kronenberg, BSc OT (Zuyd University), BA Education (De Kempel)}

International guest lecturer in Occupational Therapy, PhD candidate, University of Cape Town, Director Shades of Black Works

\section{Elelwani L Ramugondo, BSc OT (UCT), MSc OT (UCT), PhD (UCT)}

Associate Professor, Division of Health and Rehabilitation Sciences, Faculty of Health Sciences, University of Cape Town

For over a decade, debates in occupational therapy have extended into the profession's theoretical foundations as well as epistemological underpinnings thereof. A series of proposals have emerged from around the world that aim to link the definition of occupational therapy, its knowledge and practices to contemporary social, political, cultural and economic conditions. Contributing to this is the increasing precariousness of the global social life, the economic crises of many social systems, and the deterioration of the ecological environment. The current paper critically reflects on the historical conditions that shape the institution of occupational therapy, particularly in the regions of South America and Africa. This involves a political, ethical, and epistemological rethinking of the foundations that underpin identities, knowledge and practices of occupational therapy and their effects on society. These foundations may favour processes of exclusion and ahistorical and individualist views of human occupation, as opposed to social perspectives expressed in collective occupations and human rights promoting practices. The authors propose to problematise the construction of a professional identity, knowledge and practices of occupational therapy, emphasising the need for a liberating discipline, committed to and acting alongside people and communities who are in situations of social exclusion. This implies the necessary positioning of occupational therapy within social transformation.

Key words: Southern, critical, epistemologies, human occupation, human rights

"Al fin y al cabo, somos lo que hacemos para cambiar lo que somos"l:III. ("At the end of the day, we are what we do to change who we are").

Eduardo Galeano, 1998 - Uruguay

"The question of what Africa means stands unanswered at the ideological core of Pan-Africanism, negritude, nationalism, decolonization, and all other projects through which Africans have sought to understand and restore their violated humanity" $2: 1 x$

Pius Adesanmi, 20I I - Nigeria

\section{INTRODUCTION}

\section{See Note I.}

Africa has for the first time been afforded the opportunity to host the congress of the World Federation of Occupational Therapy (WFOT) in 2018. This is a great opportunity for the continent to share how occupational therapy has been and is being shaped in this particular region of the world since it was first introduced by colleagues from the global north in South Africa in 1942. South America was granted the same space in 2010 , during which keynote speakers invited considerations of the construction of identities, epistemologies and practices of occupational therapy in Latin America and Africa, two continents which are still largely portrayed as a 'developing world' or 'southern' societies. The authors adopt

Note I: This paper presents an updated, blended version of the first two authors' keynotes at regional occupational therapy conferences, respectively: "The Construction of Identities, Episteme and Practices of Occupational Therapy in Latin America", Confederación Latino Americano de Terapia Ocupacional (CLATO) in Sao Paulo-Brazil, I I-I4 October 20 I I; and "Expanding Horizons: Occupational Therapy for a Developing World", Occupational Therapy Africa Regional Group (OTARG) in Livingstone, Zambia, I2-16 September 20 I I. It also reflects a complex intercultural dialogue which had to be negotiated in Spanish and English between two continents which share similar historical socio-political conditions, attempting to bridge the WFOT world congresses of South America (Santiago de Chile, 20I0) and in Africa (Cape Town, 2018). here the term 'southern' from the Australian sociologist Raewyn Connell who uses it "not to name a sharply bounded category of states or societies, but to emphasise relations - authority, exclusión and inclusión, hegemony, partnership, sponsorship, appropriationbetween the intelectuals and institutions in the dominant European and North American metropole and those in the world peripheries, those groups and identities that sit outside the hegemonic conception of society" 3 :viii-ix.

The intention in 2010 was to inconvenience the prevailing discourse of occupational therapy and to promote a critical, reflexive stance on the profession itself. This discussion paper seeks to re-energise collective professional thought and conversation in anticipation of the 2018 WFOT congress in Cape Town, South Africa.

\section{PROFESSIONAL CONGRESSES: CONTESTED INSTITUTIONAL SPACES}

Professional congresses can be privileged places to reflect and problematise the foundations, practices and historical contexts in which a discipline is developed. But congresses can also become complacent spaces of institutional narcissism in which the actions, actors and methods of the profession's constituencies are legitimised through self-referential presentations, dialogue and publication. Congresses often have more to do with the social validation of the institutional discourse, than with promoting the exercise of citizenship of individuals and groups to which the profession dedicates its service. While the former is of interest, the profession must also place the advancement of the civic freedoms of individuals and their communities always at the center of its collective deliberations such as those that unfold at congresses.

A review of the international literature suggests that professional discourse is currently influenced by an historical period that is marked by the ideologies of neo-liberalism and pragmatism, which deny the existence of society and position individuals by themselves at the centre, dissociated from relations and the community, and the focus is on skills competition and self-management $4,5,6,7,8,9,10,11,12$. 
These and other economic and socio-political ideologies exert pressure on professions such as occupational therapy to legitimise their existence for example the increased emphasis on evidencebased practice as a means of demonstrating cost-effectiveness and instrumental efficiency ${ }^{13,14,15}$. While the macro systemic contexts in the 'developed' global north and 'developing' south may differ, they inevitably shape the discourse and various identities of the profession in locally particular ways. The dynamics at play call for reflection and a critical look at the conditions under which our professional congresses come about. It is important to interrogate the historical conditions that have led to our present identities, epistemologies and practices: What may be the limits of our constructions? What are the conditions of possibility in the 'southern contexts' of Latin America, Africa and, perhaps we can add, the peripheries of local societies globally $y^{3 \text { viii-ix? }}$

\section{Constructing the legitimacy of institutions}

We will first focus on the institution of occupational therapy, a social entity or instrument. By institution we also mean a material, organisational, symbolic structure, which mandates the actions of individuals or groups of people in a given setting. An institution transcends the wills of individual members and, presumably, orients them towards a particular social good for those who constitute it. As representations of society, institutions are also products of history, which claim to meet social needs. In this sense, institutions are based on social or societal demands. This socially oriented mandate implies that institutions, including occupational therapy, are part of the body of society and oriented to the purpose that a particular society has defined for its members. In other words, institutions contain standards and principles that sustain them. In our case, occupational therapy is primarily an institution that is located in the scientific sphere-a discipline, one of social intervention-a service profession.

As an institution, occupational therapy has methods, practices, discourses, schools, books and and academic spaces such as congresses, which legitimise it as a recognisable service profession that can be accredited by state institutions. Its practice of scholarship is further legitimised as distinct by a focus on human occupation as an object of study. A distinguishing and therefore legitimising function of occupational therapy is its exploration, explication and application of human occupation as a means towards health and well-being and as an end in itself. The processes of gaining and maintaining institutional legitimacy involve relations of power, and the ability to manage strategies of influence, domination, and social positioning including ways to shape the world and knowing how to operate in it. Consensus, contradictions and controversies characterise the distinctive focus on the construct and construction of human occupation and therefore warrant institutional consideration.

Knowing, knowledges, practices and identities are constructed in the context of a social institution and never outside of it. All knowing, that can be called science, and any practice that can be called professional in occupational therapy, falls within the institutional realm and not outside of it. Herein lays a risk, which is further elaborated on throughout this discussion paper with the aim of precipitating institutional reflexivity about the potential contribution of the WFOT 2018 congress to professional legitimacy.

\section{WFOT 2018 Congress: institutional implications} of the lead theme

In ushering the WFOT 2018 Congress to African shores, the theme arrived at in consultation with the Occupational Therapy Association for South Africa (OTASA) is boldly, "Connected through diversity, positioned for impact". A focus on diversity in the theme, given the location of the congress in South Africa, will not come as a surprise to many occupational therapists. South Africa is perceived all over the world as a country that managed to navigate a potentially politically explosive period 'without' bloodshed during the transition from an Apartheid State to a democracy in 1994. The peaceful political transition, supported by an internationally acclaimed Constitution, plotted a way forward for its extremely diverse society towards greater connectivity in building national unity. A number of phrases have been coined to describe this near-miracle transition in the context of social diversity. At that time, Emeritus Archbishop Desmond Tutu referred to South Africa as the 'Rainbow Nation'. Another well-known phrase, first uttered by Nelson Mandela, regarded widely as the father of the South African nation, appears in the preamble of the national constitution: "South Africa belongs to all who live in it, united in our diversity" 16 .

The meaning of the word 'impact' is debatable, depending on the particular leanings of practice which different communities of occupational therapy subscribe to. Those with occupational justice leanings may for example argue that, in line with human occupation-centred practice, 'impact' implies that the profession increasingly positions itself to contribute to the eradication or at least, reduction of the social conditions that create barriers to meaningful human occupation. Foregrounding notions of 'connectedness', 'diversity', 'impact' and positionality in the lead theme of an international professional congress, raises expectations that critical reflexivity will occur about institutional constructions that may have legitimised some knowledge's, practices and identities to the exclusion of others.

\section{- The lead theme and examining institutional constructions}

If occupational therapy is a social institution convened to contribute to solving social problems, what then are the ethical and political implications of pursuing particular foci such as human occupation in the context of social diversity? Social problems are not abstract. They are about people, groups, specific groups, some of whom are privileged ('Minority World') whilst others ('Majority World') are situated in marginality, vulnerability, suffering and loss of social well-being, contextual conditions that have profound implications for human occupation ${ }^{17}$. If occupational therapy is an effect, an institution that arose as a consequence of social realities, then the profession cannot examine itself without putting itself in the context of these realities. Given these realities, how then do we construct our identities, knowledge and practices?

Social problems do not affect everyone equally. Important questions to ask thus are: who are the people with whom we work? And who are we to also serve, as mandated by the World Federation of Occupational Therapists' (WFOT) position papers on Community Based Rehabilitation (2004) ${ }^{18}$, Human Rights (2006) ${ }^{19}$, Disaster Preparedness and Response $(2007)^{20}$, and Diversity and Culture $(2010)^{21}$.

\section{- The lead theme and institutional realities: Southern examples}

Currently in Chile, there is significant growth of the workplace and the employability of occupational therapists, including work in prisons. There are more jobs, better salaries, greater social legitimacy, and a gradual increase in the number of occupational therapy training programs (particularly at private universities) and government mandated occupational therapy services ${ }^{22,23}$.

In South Africa, marginal growth is apparent in access to occupational therapy for communities with no historical exposure to the profession ${ }^{24}$. In private practice, the authors have observed that emergent black middle class children with barriers to learning have become a valuable client group. The sedentary lifestyles associated with technology have limited childrens' engagement in opportunities for physically active play. Occupational therapy offers them potential benefits for postural control, fine motor coordination and visual-motor integration ${ }^{25}$.

From these and other developments within the profession, South African and Chilean occupational therapists build personal life projects and gain sustained employability. While there is nothing wrong in occupational therapists making themselves available for clients who can pay for services, it is important to recognise the ethical and political foundations that should guide access to our services, especially when the majority of the population continues to face different forms of social exclusion ${ }^{6}$. 


\section{THE IMPLICATIONS OF INSTITUTIONAL REFLEXIVITY}

The inclusion of those that are currently excluded from occupational therapy services cannot happen without constant institutional reflexivity using a set of normative principles. A caveat applies. It will always be dangerous for professions as institutions including occupational therapy to place themselves at the centre of reflexive processes. The danger lies in the disruptions that may ensue when the status quo of institutional practices are challenged. Different professional formations stand to gain or lose when institutional reflexivity seeks to reorientate practice towards people who do not have the economic means to pay for services. Resistance to institutional reflexivity that leads to radical change is therefore understandable. In the next section, we explore the points where resistance may emerge and where transformative institutional reflexivity may occur.

\section{- Nodal points for faciliating institutional reflexivity \\ Inverting dominance}

In order to invert the dominance that continually pushes the poor and the marginalised to the peripheries of our traditional practice, it makes sense to place such communities at the center of this reflective process ${ }^{6,18,19,20,21}$. If these communities are placed at the center, what would our institutional identities, knowledges and practices then be? What position or place would we adopt in relation to their identities, knowledges and practices? Invertion of dominance will involve the deconstruction of 'taken-for-granted' occupational therapy. It would therefore not be an occupational therapy that promotes the adaptation of people to the dominant social system; that adapts people who are vulnerable and excluded from the system that excludes them or that focusses on the development of skills and know-hows so that the subjects become integrated into a marginalising context without the possibility of personal and social transformation. In fact, that is exactly the kind of occupational therapy that we are challenging in this paper. We should not want more employability, more jobs, to emerge as a result of perpetuating existing injustices. Instead, what is required is an occupational therapy that transforms, that promotes other forms of social relations and alternative forms of living. In other words, inverting dominance means looking and working beyond dominant occupational therapy institutional frames to allow other occupational therapy institutions to come about.

\section{- Generating ruptures}

Inverting dominance is only possible if the first transformation is a disruption of existing institutional foundations. The institution itself, the profession and discipline, with 'us' needs to become the specific subject of transformation. As Ignacio Martin Baró had proposed for psychology ${ }^{26}$, it is occupational therapy itself which should transform at its foundations, (re)orienting it to generate a liberating practice ${ }^{27}$. Foundational rupturing demands that we commit to freeing ourselves from the dominant institutional discourse and practice. Going beyond its bounderies, generating ruptures, dissonance and disequilibrium in what is considered stable and enduring. The outcome of the first transformation is likely to be an occupational therapy that goes beyond borders and margins set to produce other occupational therapies ${ }^{15}$.

\section{- Confronting paradigmatic bias}

A rupture such as the one we propose calls for an occupational therapy produced from practices, and everyday life experiences that are locally situated and unfold, alongside specific communities. Ruptures happen when we question paradigmatic biases that situate social processes as tangential (of little relevance) to the work of the insitutution. Not thinking about our paradigmatic biases is called a-historicism; when what we do is placed in an abstract position, de-ideologised and naturalised. An example of a paradigmatic bias is extreme individualism in the understanding of and actions in our professional practices $^{8,10,12}$ (see Vignette I).

\section{Vignette I - 'The Spring Project' at Lentegeur Hospital, Cape Town}

The Lentegeur Spring Project, in which the occupational therapy department plays a key-role, was initially conceived in mid-2010 and with the backing of hospital staff and the CEO adopted by a newly established Facility Board at the hospital made up of community members. The ultimate purpose of the project is to re-design what a psychiatric hospital looks like, feels like, is and does, using the metaphor of spring (as the natural rebirth of hope) to transform it from a place of rejection into a centre of healing for individuals, communities and the environment.

One initiative of the project is the 'NORMALITEE and MALADJUSTED T-shirt Campaign'. It was developed by $\mathrm{Dr}$ John Parker and Mr David "Porky" Hefer a well-known Cape Town designer as a personal response to the two problems: I) the stigmatisation of those who are identified with psychiatric disorders coupled with a global denialism on many levels, from the personal to the political of the extremely high and growing prevalence of such disorders; and 2) the widespread phenomenon of social and moral breakdown, which together with rampant consumerism, is leading to multiple problems on our planet.

The quotes on the backs of shirts further emphasise this concept by questioning our assumption that "normal" as a measure of being well-adapted to a society that is plagued by multiple problems, is inherently a good thing. Quotes on the front and the back of the T-shirts read: (front) 'Nor-Mal' - (back) "It is no measure of health to be well-adjusted to a profoundly sick society” (Krishnamurti) and (front) 'Mal-Adjusted', (back) “... there are some things in the world to which we should never be adjusted" (Martin Luther King).

There has been wide consultation with regards to the acceptability of this campaign and support was from members of the Western Cape Mental Health Review Board, Cape Mental Health, CCAB, the Consumer group of the Gauteng Mental Health Society, Ubuntu and large numbers of people with lived experience of mental illness, all of whom have given their enthusiastic support (source: personal communication $\mathrm{Dr}$ John Parker, 8 Sept 2014) (Facebook: https://www.facebook. com/lentegeurspringproject Youtube: https://www.youtube. com/watch? $v=$ qaeTq7neOPw Finding the spring: John Parker at TEDxPrinceAlbert).

\section{Vignette 2 - 'Grandmothers Against Poverty and Aids', Khayelitsha, Cape Town}

The Khayelitisha-Cape Town based NPO Grandmothers Against Poverty and Aids (GAPA) may was founded in 200 l by a group of ten grandmothers and the South African occupational therapist Kathleen Brodrick. An initial assessment of the lived realities in context was carried out by the grandmothers themselves, supported by the occupational therapist. It quickly became clear that the many challenges, which included but went beyond medical issues (eg. poverty, lack of education, domestic violence) required the organisation to go beyond a traditional institution-based, biomedical model, individual client approach, towards a community-based, collective (occupations), self-help groups approach. A program was created that allowed the grandmothers to come together, to share, to listen, to learn, to plan and to implement the types of support that they required in order to meet their extremely challenging everyday needs. In this regard, occupational therapy became 'a multiple dimensions resource' to support the grandnothers to support themselves and each other. (Website: http//www.gapa. org.za/ Facebook: https//www.facebook.com/pages/GAPAGrandmothers-Against-Poverty-and AIDS/I08121155934330). 


\section{- Tapping into historical existences}

An occupational therapy that promotes autonomy of choice, and engaged citizenship and which considers the community as an acting subject is a producer of its own institutional reality. Generating practices of occupational therapy that are recognised within communities and that are regarded as having an effect on them means tapping into local histories. These communities possess a historical existence. Their current stories are concretely situated in intergenerational narratives. They emerge from realities that are socially produced in defined contexts. Tapping into historical existences allows occupational therapy to be produced through and in the same scenarios, contexts and places (see vignette 2 on page 5).

\section{- Moving beyond the single story}

We speak of identities because consensus exists that identity can only be understood in relation with others, hence plural. Plural identities do not only refer to differences in place, context, and historical positions but also in understandings or foundations 9 . Basically, identities refer to a symbolic universe in which a set of socially produced meanings converge ${ }^{28}$, intersubjectively, which orders and structures the life of the institution. Talking about the danger of the single identity or story, the Nigerian author Chimamanda Ngozi Adichie states that 'the single story creates stereotypes, and the problem with stereotypes is not that they are [necessarily] (inserted by authors) untrue, but that they are incomplete [...] they make one story become the only story'29. There is no single story, and neither does a single identity exist in a single person, a household, a community or a country. So too, in our occupational therapy institution there exists no single identity'. Since the $31^{\text {st }}$ of October $201 \mathrm{I}$, it is estimated that there are more than seven billion humans inhabiting the earth ${ }^{30}$. And they or really we, are all both the same and yet singularly unique. Given that every human being is unique, thus every occupational therapist is also unique, as well as all the people whom we work ${ }^{8}$.

Thus, it does not seem appropriate to speak of occupational therapy as a kind of 'monoculture', but of occupational therapies, or perhaps rather of 'an ecology of human occupation-based practices', which include but are not limited to traditional occupational therapy?.

\section{- Challenging institutional monoculturalism}

Monoculturalism refers to the privileging of a dominant culture as the singular point of reference for institutional existence. Current debates about practices and the construction of a diversity of foundations clearly puts the mono-cultural view of occupational therapy into question 9 , 18,19,20,21,27, 31,32,33.

Here we refer not only to geographic or epistemological positions, but mainly to the foundation of monoculturalism located in 'the dominant European and North American Metropole's, that has served as reference point for substantiating our understanding of reality subjects and human occupations. There is no such thing as 'no place', neither just 'one place'. There are many places of institutional articulation creating different knowledge foundations (epistemologies), axiological (value) orientations and ontological (concerned with the nature of being) assumptions, all of which help us to understand and produce occupational therapy, both its disciplinary and professional aspects. That is, there are occupational therapies'. In the next section we examine some of the dynamics at play in the emergence of southern occupational therapies. We propose critical issues of identities, epistemologies and practices that warrant consideration at collective institutional gatherings such as international congresses.

\section{EMERGING SOUTHERN IDENTITIES}

Appreciating the notion occupational therapies implies recognising identities, diversity, difference, and a variety of positions and articulations of understandings of the real. As a social institution, professionally and academically, occupational therapists are challenged to address seemingly irreconcilable north-south identity differences. This challenge is not primarily a conceptual issue, pertaining to knowledge, but primarily-one of values, practices and histories. We are interested in the effects of our professional actions, both as reproducers and transformers of the existing social order. Ramugondo's notion, 'occupational consciousness' explicitly speaks to this interest; defined as an ongoing awareness about the dynamics of hegemony, and how through what people do every day dominant practices are sustained, with implications for personal and collective health and wellbeing ${ }^{34,35}$. It is imposible to escape the political and ethical implications of our actions ${ }^{6}$. Recognising the existence of multiple occupational therapies and therefore identities results precisely in appreciating these effects and implications in the production of subjects and realities.

\section{- What is the role of occupational therapy?}

As occupational therapists we have often reflected on ourselves as subjects. At how many conferences do we ask ourselves what is the role of occupational therapy? Our mandate in answering this question has for a long time been the pursuit of a singular role, a specific social function, clear and defined. This pursuit unfolded within rationalist, objective, positivist modernity, where it was possible to think of a unique, homogeneous, absolute and stable world, one in which a uniform institutional identity was able to exist. In today's post-modern age, the objective and the permanent is no more, they are gone. There is no one truth or essence. The objective is replaced by relativism and the contingent.

\section{- How do we avoid reductionism?}

How can we ensure that, via the construction of identities, we are not looking for this bounded or determined area, which of course, separates us from other disciplines, as if the world could be simplified, reduced to precise and fixed limits? Morin's and Hegel's grand idea of 'totality' and socio-historical approaches have warned us about this propensity for reductionism ${ }^{36,37}$. Morin tells us that reality, thinking and knowledge are all complex and that is why we must use complexity to understand the world ${ }^{36}$. In the theory of complex thought devised by Morin, it is said that reality is understood and explained simultaneously from all possible perspectives, which strongly resonates with "human occupation for health', the fundamentally transdisciplinary conceptual lens that inspired the foundation and promotion of the occupational therapy profession in the early twentieth century ${ }^{38}$. It is understood that a specific phenomenon can be analysed through the most diverse areas of knowledge, through a trans-disciplinary understanding, or as Chana and Alburquerque propose 'transaberes' (Spanish), transknowledges $^{39}$ and de Souza Santos 'an ecology of knowledges'40, avoiding the usual reduction of the problem to an exclusive matter or question of science in which we participate ${ }^{41}$.

\section{- Which historical conditions have produced these identities?}

Therefore, the authors think the question is less about identities, but about conditions of possibility and production from which professional identities emerge, that is, the historical conditions that produce these identities. We must critique the naturalisation of identities. But identities also possess certain temporary 'fixations', or particular perspectives on 'human occupation' or 'human occupations' - the central focus of our profession. Like our identities, human occupations are also socially and historically produced. There is no human occupation that exists by itself. Any singularisation is the manifestation in a subject of an occupational field that is relational in character. What we collectively construct within the profession as 'human occupations' relate to our epistemologies, that is, to scientific knowledges. Next we will offer a set of reflections in this regard.

\section{EMERGING SOUTHERN EPISTEMOLOGIES}

First, why speak of epistemologies, and not epistemology? Is there not only one kind of science and one way of conceiving it? Epistemology is a discourse, a discourse of science ${ }^{41}$, which pertains to things that are said about something, for example, human occupation. Epistemology is not asking about the object of study, but about the discourses referring to the object. Discourse, i.e. the things 
that are said, are spoken by someone who is situated in a specific, social reality. In our case, this someone or subject is the institution of occupational therapy.

Secondly, what may be good for one is not good for another. It involves a democratisation of the profession, knowledge and knowing, which resonates with what the Indian scholar Shiv Visvanathan coined 'cognitive justice' 42 . He commented on the destructive impact of hegemonic Western science on 'developing countries' and non-Western cultures, calling for the recognition of alternative sciences or non-Western forms of knowledge. He argued that different knowledges are connected with different livelihoods and lifestyles and should therefore be treated equally $y^{42}$. Boaventura de Sousa Santos also employs 'cognitive justice' as a critique on the dominant paradigm of modern science, promoting the recognition of alternative paradigms or alternative sciences by facilitating and enabling dialogue between often incommensurable knowledges ${ }^{40,43}$.

Every discipline is constituted through an object of study and a method. The scientific method is generally used for the object of study of occupational therapy. Although there are knowledges and ways of knowing that are derived from experience, the empirical is most often regarded as substantive knowledge.

\section{- Which discourses sustain occupational therapy?}

Questions that unearth the underlying discourses in occupational therapy and human occupation are: What is said about occupational therapy and why was this said? From what foundation is what is said about human occupation, said? Here the intent is not to look at the object, but at the subject that speaks about the object. In this case, we assert that the subject which speaks is the institution of occupational therapy.

Epistemology is the resource that affords scientific status, a discipline's autonomy, to no longer being a supplement of something else, alongside others, but to be itself. How much of the construction of epistemologies is concerned with knowledge-knowing, and how much has this to do with the political need for validation as a scientific entity? For example, in its 2017 Centennial Vision, the American Occupational Therapy Association insists that occupational therapy (among other qualifications) is a 'science driven profession' ${ }^{44}$.

Our task in this paper is to investigate the grounds which sustain the epistemological discourses of occupational therapy. This is not a cognitive process, but the ontological rationality which establishes the assumptions of the reality of being, of human occupations. This is not an idea, cognition or a thought, but an operation of thinking that suggests the thought ${ }^{41}$. It is fundamentally a political rationality. Reflecting on the foundation of something is asking ourselves what constitutes us, what makes us understand and see what is real, what is reality in one way and not another. These are the conditions of possibility of our discourses.

Questioning the foundations is interrogating our selves. The prominent Chilean epistemologist, Carlos Pérez points to which foundations, i.e. under what historical conditions something is said about something ${ }^{41}$. That is, questioning as occupational therapists, under what social and historical conditions we say about human occupation what we say it is?

We are all situated in a historic, concrete, epistemological place. As noted by our Colombian colleague Lyda Pérez: 'we all have ways of knowing and forms of knowledge, though we may not be aware of these' (personal communication, 13 October 20II). The challenge, then, is to have self-awareness of it. For this, we must historicise the conditions of knowledge production. Historicising from what foundations we speak and act. Thus, there are multiple places, various assumptions of what is real, and various epistemologies. This implies that identities are constructed from various epistemologies.

\section{- Why is science not the only way to know in occupational therapy?}

Another aspect of the epistemological, relates to knowing and knowledge. Is science the only way to know in occupational therapy?
If we say that our discipline is science and art, is the foundation of the above just epistemological, scientific?

If the center of the work of occupational therapy is the community or groups, as previously alluded to, then the center of knowing and knowledge will also be here, not as objects but the community as an acting operant subject. From this perspective, the centrality in the community is the everyday, the world of everyday life (see vignettes).

This realm calls for a rationality that is common sense. Common sense as knowledge, of individuals and groups with whom we work. This is not an empirical knowledge, but an experiential practical knowledge, phronesis or practical wisdom ${ }^{8}$. It is the natural ability of groups and communities to operate from a shared symbolic code, which allows the perception of reality, and the attribution of meaning to people, objects or situations, which result as obvious to the common members of that community.

Carlos Peréz, referred to earlier, noted that common sense is a complex historical construction of an unsuspected depth, that we operate successfully in it on a daily basis in most of our actions, and that we rarely need to go beyond their formulations to solve common problems ${ }^{41}$. It has also been called 'reasonableness', being reasonable, which is different from being rational. It is about a common space, a set of beliefs that emerges from and is sustained by the daily practices at micro and macro social levels, intersubjective in nature and that has the character of knowledge. Also, we ought to assimilate what Bourdieu has called 'practicalities', which concerns more so an internalisation of the externality, of the knowledge that seeks to incorporate the need of the social world ${ }^{45}$. Occupational therapy does not have a unique way of knowing and to know. If this were so, it would enclose us and restrict us. Occupational therapy has the possibility of various ways of knowing and knowledge and science, a particular kind, is one of them. As noted by Kronenberg, Pollard and Ramugondo: "... occupational therapy is fundamentally a posibilities-based practice, which generates evidence-based practice via practice-based evidence" $46: 11$.

\section{- How can substantive institutional knowledges be built?}

Can knowledge for occupational therapy be built from experience and from the empirical? What we regard as central to occupational therapy is the common sense knowledge of daily practice, the everyday sense, and science is to be articulated, anchored in this knowledge. It ought to be articulated with a multiplicity of actors, bringing about ways of knowing and forms of knowledge with real people and communities in their everyday life contexts, guided by their interests, allowing our profession to become a particular knowledge in service of the community (see vignettes) (,27. $^{2}$.

Occupational therapy knowledge is found in the practices themselves, in human occupations, not outside of them. It is found in occupational experiences. The human occupations are not something external to the subjects, a method to achieve the essence through this phenomenon called 'human occupation'. The human occupations are social practices, relationships, in which subjects are constituted and produced. Occupational therapy knowledge is not beyond that. The knowledge is in the subjects themselves, in many places, in many actors. Science is but another way of understanding and knowing these knowledges. But it is in critical reflection, a problematising of the actors themselves, a questioning of common sense, from which emerges a substantive knowledge for the profession. Simultaneously, we must also problematise the assumptions that underly all scientific knowledge.

To do this, calls for critical thinking, an interrogation of reality, that is not regarding it obvious, questioning if things are as they are or may be otherwise. Critical here means questioning the method of thinking as the main aspect of knowledge construction. To be critical is to interrogate the assumptions of occupational therapy, questioning that which is considered the obvious and the natural ${ }^{9,27,31,32,33}$. Critical, is not only thinking about the political, ethical and economic issues that are affecting the community and the implications for occupational therapy, but also involves questioning from where, which and how knowledge emerges, i.e. the critical itself becomes 
a form of knowledge. In the next section we provide examples of institutional assumptions that warrant critique.

Critiquing, for example... That human occupation is healthy, that being occupied produces wellbeing and that without human occupation we get sick. Under what historical conditions did these assumptions about human occupation arise? In a capitalist world of consumption where identities manifest as individualism, with competition gone wild, which human occupations really are healthy and generate well-being? If we are produced by what we do, that is through human occupations, and these are embodied in specific socio-economic contexts, then how can one ensure in the kind of alienating, materialistic, throw-away society in which we live, that human occupations are 'outside' of this scenario and do not produce damage or ill-health? Is it possible to maintain that human occupations are 'outside' of social reality, immune and external to the subjects themselves and their relationships? Social alienation is sustained through alienating, dehumanising occupational practices (see vignette I).

Critiquing, for example... That human occupation exists, singularly, as in individuality. As previously suggested, no human occupation is understood as an abstract entity separate from its relationships with others. Every human occupation is linked to culture, meaning, and relationships.

Critiquing, for example... That human occupation is an object of study. Human occupation is not a thing, an indeterminate. It is not a mineral, a rock, a molecule, or a tissue. Human occupation is people, relationships. In occupational therapy, the object of study is not an object but a subject that thinks, acts, decides. Human occupation is not separate from the subject. The subject is 'being' in human occupation. It is neither a mediating element to the environment, nor a method of intervention. To successfully separate human occupation from people would mean that we have reified, naturalised and dehumanised the subjects. Our practices would as a result negatively affect the wellbeing of people.

The examples presented here suggest that a major challenge to building substantive institutional knowledges is to overcome the duality between subject and human occupation.

We propose to understand 'the occupational' in the Hegelian sense, as 'totality' ${ }^{37}$. That is, there are no subjects who occupy or subjects who acquire subjectivity in the psychological sense in the act of occupying. Instead, there is a field of social relations that produces reality and subjects as two entities in the same space. This field as 'totality' is human occupation, not as a particular fact, but as 'totality'.

\section{EMERGING SOUTHERN PRACTICES}

Whether interventional or theoretical, we regard both occupational therapy scholarship and practice fields as practices. Basically, practices are collective occupations, they are the foundation of occupational therapy. Ramugondo and Kronenberg propose the following working definition of collective occupations: "Human occupations that are engaged in by individuals, groups, communities and/or societies in everyday contexts, which may reflect an intention towards social cohesion or dysfunction, and/or advancement or aversion of a common good"12:8. Practices must be concrete and situated which in this discussion paper is in the contexts of Latin America and Africa.

All practice is a social act. No practice is individual, not even when it is carried out by a single person. All human occupation makes reference to a context, to a personal sense, to a process of cultural appropriation. All that can be called individual is the singular materialisation of a collective occupational field.

Our central concern are communities and specific groups and the fundamental purpose, as noted by Nobel Peace Prize laureate Desmond Tutu, is to help bring about the welfare of people associated with the struggles against injustice ${ }^{47}$. Or as Kronenberg puts it, contributing to prospects of humanising collective occupations (see vignettes), advancing society's understanding and appreciation of 'doing well-doing right together'8,48,49.

Likewise, Simó asserts that practices must be consistent with sustainable development, since human occupation is the means to recycle, relocate, reduce, and reuse resources available to us. We can conceive of human occupation as a dialogue between human beings and the natural environment. This Simó called occupational ecology ${ }^{50}$

Also referring to practices, Ramugondo invites us to become more 'occupationally conscious' of what we do everyday. How what we do comes about, and implications thereof for individual and collective wellbeing ${ }^{34,35}$.

\section{- What ought to be the foundations of occupational therapy practices?}

The issues above refer not to technical or methodological matters of practices, or two of Aristotle's three intellectual virtues, namely episteme (scientific knowledge) and techne (applied scientific knowledge), which according to Flyvbjerg produce 'instrumental rationality' ${ }^{51}$. On the contrary, these issues correspond with political and ethical considerations regarding what ought to be the foundation of occupational therapy practices. Such considerations resonate with Aristotle's third intelectual virtue phronesis (practical wisdom), which Flyvbjerg says produces 'value and power rationality' ${ }^{51}$, which relates to Pérez's 'reasonableness'. ${ }^{41}$. Practices are not primarily instrumental. In their foundation, what underlies practices are political and ethical conceptions of those who and that which must be transformed. In this regard, in her closing keynote at the 2010 world congress of the World Federation of Occupational Therapists in Chile, Galheigo highlighted the need to reflect on the political and ethical dimensions of occupational therapy ${ }^{6}$.

Correspondingly, all occupational therapy practice is a political practice $^{52,53}$. It is political because it deals with a concrete world, with a particular society, with a world that we want to build. It relates to the kind of subjects that are produced by our actions in a neoliberal society and market, with a desired type of governance. It is political because we produce ourselves from social problems. And because we question ourselves from a reality in which we are of and take part in.

\section{- What value judgements guide our institutional practices?}

If this is so, it necessarily involves value judgments, forms of relationships that allow establishing what is fair and what is not fair, which relates to Kronenberg's occupational therapy adage 'doing well-doing right together'8. Such a practice is political as it has to do with the common good and the public. It requires consideration of who the other or others are. This involves ethics, in terms of acknowledging the existence of otherness. However, the ethical and political dimensions of occupational therapy have been denied, subtracted from the foundation of occupational therapy. Subtracted by rigorous militancy, by the needs of professional associations and unions, and the need for social legitimacy of being a positivist scientific discipline ${ }^{33}$. The scientific foundation that has dominated us is a-historic, a-septic, and neutral.

But there is no science that is not political. Accordingly, ethics are an imperative. One possible ethic is Ubuntu and human rights another. Not the human rights of the Western capitalist world, characterised by the human rights of white, liberal and individual men, but human rights that support multiple ways of existence including 'cognitive justice' ${ }^{40,43}$. At stake here is a value system of human rights that endorses many othernesses, on a basis of equity and on acceptance of distinction and not on similarity or complementarity. Human rights as appreciating equality in difference. Such a system of human rights would recognise wellbeing as an effect of citizenship, a way of life. Valentini described it as a lifestyle characterised by a multi-ethnic world to be reflected on clandestine lives, the lives of those who are homeless, about the lives marked and led by the abuse of alcohol and drugs, the lives cut short by profound loneliness, about the lives of those fleeing countries where they face terrible wars, as well as lives that invoke instances of justice, intelligent solidarity, hope in a possible future and a meaningful existence that can always be revised and shared ${ }^{54}$. Where human rights are not something that can be accessed, arrived at, obtained in relation to shortages, but where rights are collective and lead 
to community action for the protection of vulnerable groups and individuals. Where occupational therapy practices within the human rights framework, it is not about rehabilitating capacities as a pragmatic exercise of the right, but the rights as producers of capacities.

\section{- How may we disrupt overly individualistic practices?}

As we are human occupation, at the same time, we are the right, which is the political ethical ideal that should guide the enactment of occupational therapy. In practice, we ought to break the individual methodology, that is, an overly individualistic approach of interventions that prevail in occupational therapy. There is nothing in me that is not in us. This resonates with Ubuntu, which, in a profound sense, implies an interactive ethic in which the who and how we can be as human beings is always being shaped in our interaction with each other ${ }^{55}$, which underlies collective occupations ${ }^{12}$.

The authors believe that collective occupations perspectives (see vignettes) are a key-strategy for the construction of identities, belongings and autonomy processes. All practices should enable groups' and individuals' occupational consciousness ${ }^{34,35}$ and self-consciousness. Not only the consciousness of my conditions of life in which I am produced, but self-consciousness, that there is nothing beyond human practice, that there is nothing beyond human occupations. This we can call occupational therapies, not occupational therapy, various occupational therapies and in particular; critical occupational therapy; social occupational therapy; occupational therapy without borders ${ }^{9,27}$; humanising occupations-based practices $8,48,49$ practices based on caring for sustainable ecological development ${ }^{50}$; a political practice of occupational therapy ${ }^{46,52,53,56}$.

All of them, to paraphrase Dr. Isabel Piper who refers to social psychology, 'must be practical not to solve problems to maintain the social order, but to subvert it and to transform it. Not to change the people to suit the social system, but to produce subjects who are eager to transform the social order' ${ }^{\prime 57}$. Not a practice of occupational therapy that is devoted to the discovery of who we are but to its rejection, to challenge how we have been produced in the current social order.

\section{CONCLUSION}

The intention of this discussion paper was to surface issues of critical concern to the international institution of occupational therapy as it prepares for the first ever World Federation congress in Africa in 2018. It has argued that, from a Southern perspective, there is no identity, but identities. There is not knowledge but a plurality of knowledges and many histories. There is no treatment, but political and ethical practices that manifest in different forms of social action and social and psychosocial intervention; whether community-based or clinical. The paper has suggested that there are no human occupations separated from subjects, but that we, the institution, are human occupation. In short, we have argued that, human occupation is the subject, that there is no human occupation, but human occupations, which manifest on a continuum of individual and/or collective 'doings' that are humanising and dehumanising ${ }^{47}$.

As occupational therapists from across the globe prepare to join their African colleagues at the WFOT congress in Cape Town in 2018 , we urge them to reflect on the idea that occupational therapy is not abstract, but historically and culturally situated. Historicising occupational therapy allows for the creation of a distinct foundation for the discipline and the profession. Historicising implies that there is nothing beyond human practice itself. There is no reality outside of social relations. Relations are produced under concrete cultural, economic, political, territorial, spatial and temporal conditions. Relations, such as occupational practices, pre-exist subjects and as such we are the effect of this occupational field. Taking such a position in thinking about the profession has two implications that we considered important for the deliberations at the Congress in 2018. Firstly we proposed the possibility of transformation, realisation and freedom that exists in the field of occupational practice and not in forces, laws or a natural condition that precedes and exceeds the subjects. Secondly, we proposed that there is a methodological im- plication, that if the subject is a product of a particular occupational field ('we are human occupation'), then all action in the professional realm must assume that there is no individual human occupation that is not social and that any intervention requires assuming collective occupational perspectives for understanding human occupation as a personal, individual fact. As the profession moves towards 2018 , we anticipate increased engagement with Southern identities, epistemologies and practices for the advancement of the global institution of occupational therapy.

\section{REFERENCES}

I. Galeano, E. Patas arriba: la escuela del mundo al Revés. Siglo XXI Editores. Madrid. I998: I II.

2. Adesanmi P. You're Not a Country, Africa: A Personal History of the African Present. Johannesburg: Penguin Books, 20I I: ix.

3. Connell R. Southern Theory: The global dynamics of knowledge in social science. Australia, Allen \& Unwin Epz. 2007: viii-ix.

4. Clouston, T.J. Whose occupational balance is it anyway? The challenge of neoliberal capitalism and work-life imbalance. British Journal of Occupational Therapy. 20I4; 77 (3): 507-5I5(9).

5. Frank, G. Occupational Therapy/Occupational Science/Occupational Justice: Moral Commitments and Global Assemblages. Journal of Occupational Science, Journal of Occupational Science. 04/2012. 201 ; I9(I). DOI: 10.1080/1442759I.

6. Galheigo $\mathrm{S}$. What needs to be done? Occupational therapy responsibilities and challenges regarding human rights. Australian Occupational Therapy Journal. 20I I; 58: 60-6.

7. Hammell, K.W. Beyond deficits: Perspectives on well-being and occupational therapy. Thelma Cardwell Lecture, University of Toronto. 26 June 2013. Available: http://www.ot.utoronto.ca/research/ research_day/documents/rd_13_lecture.pdf

8. Kronenberg, F. Doing Well-Doing Right Together: A practical wisdom approach to making occupational therapy matter. New Zealand Journal of Occupational Therapy. 2013; 60(I): 24-32.

9. Kronenberg F, Pollard N, Sakellariou D. Occupational Therapies without Borders - Volume 2: Towards an Ecology of OccupationBased Practices. Oxford: Churchill Livingstone-Elsevier. 201 I.

10. Laliberte-Rudman, D. Enacting the Critical Potential of Occupational Science: Problematizing the 'Individualizing of Occupation'. Journal of Occupational Science. 20 I3; 20 (4): 298-3 I3

II. Pollard N, Sakellariou D, Kronenberg F. A Political Practice of Occupational Therapy. Churchill Livingstone-Elsevier. 2008.

12. Ramugondo EL, Kronenberg F. Explaining Collective Occupations from a Human Relations Perspective: Bridging the Individual-Collective Dichotomy. Journal of Occupational Science. (2013). DOI : 10.1080/I442759I.2013.781920 To link to this article: <http:// dx.doi.org//0.1080/1442759|.2013.781920>

13. Website: Evidence Based Occupational Therapy. www.otevidence. info

14. Blog: Terapia Ocupacional Aplicada Basada en la Evidencia Cientifica, Blog de la Universidad Miguel Hernandez de Elche. España, 2009/20 I0. Available: http://scopeo.usal.es/terapia-ocupacionalbasada-en-la-evidencia-cientifica-umh-20092010/

15. Sánchez Cabeza, Á. Terapia Ocupacional basada en la Evidencia para la rehabilitación del daño cerebral adquirido. TOG (A Coruña) [revista en Internet]. 2013; Vol 10, Supl. 8: pp. 40-53. Available: http://www.revistatog.com/suple/num8/rehabilitacion.pdf.

16. Government of South Africa. Preamble to the Constitution of the Republic of South Africa. Online: http://www.thepresidency.gov.za/ docs/reports/annual/2008/preamble.pdf, 1996.

17. Thibeault, R. Globalisation, universities and the future of occupational therapy: Dispatches for the Majority World. Australian Occupational Therapy Journal. 2006; 159-165.

18. World Federation of Occupational Therapists. Position paper on Community-Based Rehabilitation. 2004. <https://www.wfot.org/ office_files/CBRposition \%20Final\%20CM2004\%282\%29.pdf> (2I Jan 20I5)

19. World Federation of Occupational Therapists. Position statement on Human Rights. 2006. <https://www.wfot.org/office_files/ Human\%20Rights\% 20Position\% 20Statement\%20Final\%20 NLH\%28I\%29.pdf > (2I Jan 20I5)

20. World Federation of Occupational Therapists. Position statement on Disaster Preparedness and Response. 2007. <http://www.wfot. org/documents/DP\&RContents.pdf > (2I Jan 20I5) 
21. World Federation of Occupational Therapists. Position statement on Diversity and Culture. 2010. <http://www.wfot.org/ office_files/Diversity\%20and\%20 Culture _\%20Final\%20Version July2010\%28I\%29.pdf > (2I Jan 2015)

22. Ministerio de la Salud. Desarrollo Metodologico de la Rehabilitacion Integral en APS y Hospitales de Menor Complejidad. Santiago: Gobierno de Chile. 2007.

23. Ministerio de Educación en Chile. El Servicio Nacional de Informacion. 20I2. <http://www.mifuturo.cl/> (2I Jan 20I5)

24. Maseko, L. J; Erasmus, A; Di Rago, T.; Hooper, J. ; O’Reilly, J. Factors that influence choice of placement for community service among occupational therapists in South Africa. South African Journal of Occupational Therapy. 2014; 44(I): 36-40.

25. Rural Rehab South Africa. Submission towards the National Health Insurance. <www.ruralrehab.co.za/uploads/3/0/9/0/3090989/ ruresa_nhi_20II.doc >(2I Jan 20I5), $20 \mathrm{II}$.

26. Baró, M.I. (1995). Acción e Ideología. Psicología Social desde Centro América. UAC Editores. San Salvado, El Salvador.

27. Kronenberg F, Simo Algado S, Pollard N. Occupational Therapy without Borders: Learning from the Spirit of Survivors. Edinburgh: Churchill Livingstone-Elsevier. $20 \mathrm{II}$.

28. Montero M. Teoría y Práctica de la Psicología Comunitaria. Buenos Aires: Edit Paidos. 2006.

29. Adichie C. The danger of the single story. TED talk. 2009. <http:// www.ted.com/talks/chimamanda_adichie_the_danger_of_a_single story.html > (2I Jan 20I5).

30. United Nations. World population 7 billion. 20I2. <http://www. worldometers.info/world-population/> (21 Jan 2015)

31. Hammell, K.W. Resisting theoretical imperialism in the disciplines of occupational science and occupational therapy. British Journal of Occupational Therapy. 20II; 74(I): 27-33.

32. Hammell KW. Sacred texts: a sceptical exploration of the assumptions underpinning theories of occupation. Canadian Journal of Occupational Therapy. 2009a; 76(I): 6-13.

33. Hammell, KW Self-care, productivity, and leisure, or dimensions of occupational experience: rethinking occupational 'categories'. Canadian Journal of Occupational Therapy. 2009b; 76(2): 107-II4.

34. Ramugondo EL. Intergenerational shifts and continuities in children's play within a rural Venda family in the early 20th and 2 I st centuries. PhD thesis, University of Cape Town, Cape Town. 2009.

35. Ramugondo EL. Intergenerational Play within Family: The Case for Occupational Consciousness. Journal of Occupational Science. 20I2; iFirst:I-I5.

36. Morín E. Introducción al Pensamiento Complejo. Barcelona: Edit Gedisa. 2007.

37. Pérez Soto C. Desde Hegel. Para una crítica radical de las ciencias sociales. Mexico: Edit Itaca. 2008.

38. Frank, G, Zemke, R. Occupational therapy foundations for political engagement and social transformation. In: N. Pollard, D. Sakellariou, F. Kronenberg. A political practice of Occupational Therapy. Elsevier, Oxford, 2008.

39. Chana, P., Alburquerque, D. Trabajo multidisciplinario, interdisciplinariedad, transdiciplinaridad y transaberes. Presentacion sobre trabajo en equipo presentada. Curso de Capacitación-Intervención: RBC. <http://www.cetram.org/dp/?q=node/228> (2I Jan 20I5), 2012.

40. Santos, Sousa, de, B. Cognitive Justice in a Global World: Prudent knowledges for a decent life. Lexington: Lanham. 2007.

4I. Pérez Soto C. Un Concepto Histórico de Ciencias: De la epistemología actual a la dialéctica. Santiago: LOM Ediciones. 1998.

42. Visvanathan S. A Carnival for Science: Essays on science, technology and development. London: Oxford University Press, 1997.

43. Santos, Sousa, de, B. Cognitive Justice in a Global World: Prudent knowledges for a decent life. Lexington: Lanham. 2007.

44. American Occupational Therapy Association. AOTA's Centennial Vision and Executive Summary. American Journal of Occupational Therapy. 2007; 61: 613-614.

45. Chevallier S, Chauvieré C. Diccionario Bourdieu. Buenos Aires: Ediciones Nueva Visón. Buenos Aires. 2010.

46. Kronenberg F, Pollard N, Ramugondo EL. Introduction: Courage to dance politics. In: Kronenberg F, Pollard N, Sakellariou D, editors. Occupational Therapies without Borders-Volume 2: Towards an Ecology of Occupation-Based Practices. Oxford: Churchill Livingstone-Elsevier. 20 I I: II.

47. Tutu D. Foreword I. In: Kronenberg F, Pollard N, Sakellariou D, editors. Occupational Therapies without Borders-Volume 2: To- wards an Ecology of Occupation-Based Practices. Oxford: Churchill Livingstone-Elsevier. 20II: ix.

48. Simo S. Universities and the global chance: Inclusive communities, gardening, and citizenship. In: Kronenberg F, Pollard N, Sakellariou $D$, editors. Occupational Therapies without Borders- Volume 2: Towards an Ecology of Occupation Based Practices. Oxford: Churchill Livingstone-Elsevier. 20 I I: 367-375.

49. Kronenberg, F. (20II). Ubuntourism: Engaging divided people in post-apartheid South Africa. In: F. Kronenberg, N. Pollard \& D. Sakellariou. Occupational Therapies without Borders: Towards an ecology of occupation-based practices. Elsevier, Oxford, 20I I Pp $195-207$.

50. Simo S. La Palabra y la Acción: Lucha contra la pobreza, salud (ocupacional) y ciudadanía a través de nuevas praxis universitarias. Tesis Doctoral. Vic. 2010.

5I. Flyvbjerg B. Making Social Science Matter: Why Social Inquiry Fails and How lt Can Succeed Again. Cambridge: Cambridge University Press. 200I.

52. Kronenberg F, Pollard N. Political dimensions of occupation and the roles of occupational therapy. Plenary address at the 2006 AOTA conference in Charlotte/NC, American Journal of Occupational Therapy. 2006; 60: 617-625.

53. Pollard N, Sakellariou D, Kronenberg F. A Political Practice of Occupational Therapy. Churchill Livingstone-Elsevier. 2008.

54. Valentini W. La ciudadanía es terapéutica. Confrontación sobre prácticas exitosas de Salud Mental en el Mundo. Municipalidad de Milán Italia: Caritas Ambrosiana. 2002.

55. Van Marle, K., \& Cornell, D. H. Exploring ubuntu: Tentative reflections. African Human Rights Law Journal. 2005; 5(2): 195-220.

56. Frank, G, Zemke, R. Occupational therapy foundations for political engagement and social transformation. In: N. Pollard, D. Sakellariou, F. Kronenberg. A Political Practice of Occupational Therapy. Elsevier, Oxford, 2008.

57. Pipper I. Políticas, sujetos y Resistencias. Cuadernos de Psicología Social. Santiago: Universidad ARCIS. 2002.

http://dx.doi.org/I 0.17 I 59/23 I 0-3833/20 I 5/v45nola2

Corresponding Authors

Alejandro Guajardo

aguajardo@unab.cl

Frank Kronenberg

Frank.Kronenberg@gmail.com 